\title{
Editorial
}

\section{Revista de Medicina (Journal of Medicine, University of São Paulo) - 100 years}

As the current head of the Department of Medicine, I was invited to write the editorial for for the special commemorative edition of the 100 years of the Revista de Medicina of University of São Paulo. I was extremely grateful for the invitation but, at the same time, I was apprehensive about a task of such importance. As an attendee of the Health Quadrilateral since 1978, I felt compelled to accept the challenge with the collaboration of my sister and USP-65 classmate, Elvira Pereira Velloso, professor of the Hematology Division of the Department of Medicine.

It is interesting to highlight the evolution of the Revista de Medicina of University of São Paulo in recent years. In 1913, with the creation of the "Centro Acadêmico Oswaldo Cruz da Faculdade de Medicina e Cirurgia de S. Paulo (Oswaldo Cruz Academic Center of University of São paulo, School of Medicine and Surgery)", the pillars of the Journal are set. It was founded in 1916 by Arnaldo Vieira de Carvalho, aiming to bring the students closer to the scientific production and provide greater integration between teachers and students. Having achieved this goal, it is nowadays the oldest academic scientific journal in circulation in the world.

In July 1916, Ovídio Pires de Campos, Professor of Physiology of the University S. Paulo, School of Medicine and Surgery, wrote the first editorial in the Revista de Medicina. This first issue addressed topics which were relevant at the time, written by professors and students with historical notoriety, such as: "Como se deve, racionalmente, preparar o caldo de cultura? (How can the culture broth be rationally prepared?)" by Dr. Geraldo H. de Paula Souza, Chemistry preparer of the University of São Paulo, School of Medicine and Surgery; "Clinica Propedêtica da insufficiencia aórtica (meios para o seu diagnóstico) Clinical Propaedeutics of aortic insufficiency (means for its diagnosis)" by Flamínio Favero, a student in the 4th year of Medicine; "Valor clinico da sôroreacção de Wassermann (Clinical Value of the Wassermann serum-reaction)", by Altino Antunes, also a student in the 4th year of Medicine. The article, "Consequências futuras da therapeutica (Future consequences of therapeutics)", by Dr. Rubião Meira, Professor of Clinical Medicine of the University of São Paulo, School of Medicine and Surgery, discusses philosophical considerations about the innovative therapeutics for three prevalent diseases (rheumatism, syphilis and amoebic dysentery), believing in the possible eradication of these diseases.

A hundred years later we can notice significant changes in the knowledge regarding Health Sciences. The development of technologies for molecular and cellular approaches, as well as imaging and minimally invasive surgeries and procedures, have been allowing for advances in diagnosis and 
therapeutics. The quick spread of this knowledge through the development of digital tools is even more spectacular.

The Revista de Medicina of Univsersity of São Paulo, published quarterly and now with its digital collection complete, has been following the globalized scientific developments, with articles published in English and its incorporation in the USP Journal Portal, allowing wide access and being a leader in access in this portal, which is the largest in Latin America. There is also a concern about expanding the advisory board and its publications to other professionals from renowned national and international universities.

In its last edition of 2015, it is worth highlighting the publication of current issues such as gene therapy and molecular diagnostics also maintaining timeless themes such as drug addiction and neurobiology of emotions, written by the professors of the University. Moreover, it features an editorial by the student and editor-in-chief Gustavo Rosa Gameiro, addressing the "New Century of the Revista de Medicina, what changes? (original title: "Novo século da Revista de Medicina, o que muda?").

The success of this Journal is due to the verve of the students of this school, represented by Oswaldo Cruz Academic Center, which keeps the thirst for scientific knowledge and its dissemination by students and professores who really love the University of São Paulo, School of Medicine. We congratulate the student Gustavo and his colleagues for this issue, hoping the Revista de Medicina, University of São Paulo will serve as an example to professors, doctors and students, dignifying and strengthening our University. We hope that our journal maintains and expands the initial goals it had in 1916: in addition to integrating professors and students and spreading knowledge generated in Arnaldo's Home, welcoming the participation of other institutions that dignify Science, Education and the Medical Profession.

\section{Rosa M Rodrigues Pereira}

Professor of the Rheumatology Division of the Department of Medicine, University of São

Paulo, School of Medicine.

Email: rosa.pereira@hc.fm.usp.br

Elvira D Rodrigues Pereira Velloso Professor of the Hematology Division of the Departament of Medicine, University of São Paulo, School of Medicine.

Email: elvira.velloso@hc.fm.usp.br 